March 2001

\title{
Measurement of the impact of Winona Health Online
}

David B. Nash

Thomas Jefferson University

David Shulkin

DoctorQuality.com

Florence Comite

Yale University School of Medicine

Ron Loeppke

PhyCor

Bruce Van Cleave

Trinity Health

Follow this and additional works at: https://jdc.jefferson.edu/healthpolicyfaculty See next page for additional authors

Part of the Health Services Research Commons

Let us know how access to this document benefits you

\section{Recommended Citation}

Nash, David B.; Shulkin, David ; Comite, Florence; Loeppke, Ron; Van Cleave, Bruce; Kane, Robert ; Christianson, Jon; and Pousma, Douglas, "Measurement of the impact of Winona Health Online" (2001). College of Population Health Faculty Papers. Paper 13.

https://jdc.jefferson.edu/healthpolicyfaculty/13

This Article is brought to you for free and open access by the Jefferson Digital Commons. The Jefferson Digital Commons is a service of Thomas Jefferson University's Center for Teaching and Learning (CTL). The Commons is a showcase for Jefferson books and journals, peer-reviewed scholarly publications, unique historical collections from the University archives, and teaching tools. The Jefferson Digital Commons allows researchers and interested readers anywhere in the world to learn about and keep up to date with Jefferson scholarship. This article has been accepted for inclusion in College of Population Health Faculty Papers by an authorized administrator of the Jefferson Digital Commons. For more information, please contact: JeffersonDigitalCommons@jefferson.edu. 


\section{Authors}

David B. Nash, David Shulkin, Florence Comite, Ron Loeppke, Bruce Van Cleave, Robert Kane, Jon Christianson, and Douglas Pousma 


\title{
Measurement of the Impact of Winona Health Online
}

\author{
DAVID B. NASH, M.D., M.B.A., ${ }^{1}$ DAVID SHULKIN, M.D., ${ }^{2}$ FLORENCE COMITE, M.D., ${ }^{3}$ \\ RON LOEPPKE, M.D., M.P.H., ${ }^{4}$ BRUCE VAN CLEAVE, M.D., ${ }^{5}$ ROBERT KANE, M.D., ${ }^{6}$ \\ JON CHRISTIANSON, Ph.D., ${ }^{6}$ DOUGLAS POUSMA, M.D., 7 \\ and THE WINONA HEALTH ONLINE OUTCOME GROUP ${ }^{7}$
}

\begin{abstract}
The purpose of this article is to present the methodology to study the clinical and financial outcomes associated with the use of Winona Health Online, a novel community-wide interactive healthcare Website in Winona, Minnesota. Outcome methodology was developed by the University of Minnesota School of Public Health and the Carlson School of Management in cooperation with nationally recognized outcomes and disease state management experts, healthcare practitioners in Winona, statisticians, and health economists. The main areas of measurement include health status, satisfaction, cost and utilization of services, and clinical quality.
\end{abstract}

$\mathbf{W}$ InOna Health Online (WHOL) is a joint venture among Cerner Corporation, Winona Health, and Hiawatha Broadband Communications, Inc. in Winona, Minnesota. WHOL offers personalized information to impact health. People within the community can become members after registering and completing a health risk assessment (HRA). Members are given Internet access to personal laboratory results sent via secure private communications, a self-populating personal health record (PHR), expert drug information, and links for trusted online medical information from their doctor. Immediate feedback from the HRA provides users with valuable preventive information. The online HRA helps identify patients with certain chronic conditions so that these individuals can be forwarded to specific and personalized online disease state management (DSM) programs that have been preapproved by their provider.

The security of WHOL's private communications between patients and their providers and a pharmacist is supported by Health Care Financing Administration (HCFA)-recommended Secure Socket Layer (SSL) 3.0 with 128-bit encryption. In addition to the standard username and password, WHOL also issues and maintains a personal digital certificate. Members have to present themselves in person with photo identification and become "validated" to send and receive messages. When logging on to a new or different computer, members are required to

\footnotetext{
${ }^{1}$ Thomas Jefferson University and Jefferson Medical College, Philadelphia, Pennsylvania.

${ }^{2}$ DoctorQuality.com, Philadelphia, Pennsylvania.

${ }^{3}$ Yale University School of Medicine, New Haven, Connecticut.

${ }^{4}$ PhyCor, Nashville, Tennessee.

${ }^{5}$ Trinity Health, Novi, Michigan.

${ }^{6}$ University of Minnesota School of Public Health and Carlson School of Management, Minneapolis, Minnesota.

${ }^{7}$ Members of WHOL are: W. Davis, M.D.; C. Shepard, M.D.; A. Olson, R.N.C.; W. McNeil, M.D.; D. Nolan, M.D.;

D. Boyer, M.D.; J. Turek, R.N.; K. Lanik, R.H.I.T., C.P.H.Q.; M. Dummit, M.D.; P. Nuzum, R.N.; S. Birdsall, M.D.;

S. Turner, M.D.; T. Taubenheim, M.S.; T. Tinstman, M.D.; D. Sides, C.H.E., WHOL, Winona, Minnesota.
} 
answer two questions they wrote so that the new computer can receive their personal digital certificate.

Mammogram and Pap smear results, along with a physician's interpretation, can be sent directly to patients who can, in turn, ask questions or request an appointment. Patients on medication can request refills or renewals from their pharmacist, who in turn can batch renewal requests to the prescribing provider or send the filled prescription to the patient's home along with an electronic "prescription filled" notice. A patient's lab results and prescribed medications can become part of the PHR at the click of a button.

More than half of Winona's pharmacies currently participate; the others are strongly considering or are in the process of interfacing. Future plans for WHOL include a system of healthcare reminders and alerts that will be "pushed" to consumers based on rules and algorithms that accept data from a variety of sources, including the HRA, the PHR, and online DSM programs.

The purpose of this article is to describe the methods that have been developed to measure changes in health associated with the use of WHOL. These outcome measurements have been designed to illustrate the value of WHOL to its different users. The general areas of study will be health status, patient satisfaction, cost and utilization, and clinical quality. Evidence of clinical benefit and return on investment will provide the impetus to improve health in future connected communities.

\section{ELIGIBILITY}

All citizens ages 18 and older who reside within 17 zip codes that represent the potential market share for the Winona healthcare delivery system are eligible for free membership in WHOL.

Membership to WHOL is being encouraged with a grass-roots marketing strategy designed to encourage people with an expected interest to promote membership among their peers by word of mouth. Several special-interest groups being targeted include schools, employers, and the elderly. Marketing tactics include the use of billboards, newspaper advertisements, and point-of-purchase displays at pharmacies and clinics. Newspaper articles that feature "the next-door neighbor" have been extremely valuable. Winona State University students in the Health Organization Promotion and Education program have volunteered to promote membership. They and other Winona State University students who receive internship credits for their work are helping disadvantaged persons, such as the elderly, to become members and begin to realize benefits.

\section{INTERVENTION}

Interventions (e.g., personalized feedback based on answers from the HRA, online DSM for persons with certain chronic conditions, secure private communications, and an online PHR) are only available to members of WHOL. Although interventions are not available to nonmembers, all users of WHOL can view generalized health information, expert drug information (a drug interaction checking application), and MedGuide-compliant patient education drug leaflets.

The HRA was co-developed by experts at the University of Virginia and Cerner Corporation (Kansas City, MO). It asks about personal and family health history; medications; emotional state and stress; use of tobacco, alcohol, caffeine, and illicit drugs; exercise; heart disease and stroke; diet; risk of injury and work-related illness; risk factors for cancer; glaucoma; immunizations; sexual behavior; pregnancy; and other general information. On completion of the HRA, users are immediately given feedback based on the answers to the survey. Entered data are stored for comparison to future survey data. Members with certain chronic conditions are placed into online disease management programs. Using prevalence rates, financial burden to the community, consequences of noncompliance/benefits of compliance, the availability of benchmark data, and other factors, the Winona medical community has chosen to study the effects of WHOL on congestive heart failure (CHF) and diabetes mellitus (DM) types I and II.

WHOL currently provides members with 
Table 1. Data Elements that Will Be Measured to Showthe Benefit of Winona Health Online by User TYPE

\begin{tabular}{|c|c|c|c|}
\hline User & Value proposition & Intervention & Data element \\
\hline \multirow[t]{4}{*}{ Consumer } & $\begin{array}{l}\text { Decreased risk for disease, } \\
\text { wellness preservation, } \\
\text { improved community } \\
\text { health. }\end{array}$ & $\begin{array}{l}\text { Person-specific risk reduction mes- } \\
\text { sage pushes, customized links to } \\
\text { online information and challenges } \\
\text { to improve, invitation to commu- } \\
\text { nity-based programs (e.g., } \\
\text { smoking-cessation classes). }\end{array}$ & $\begin{array}{l}\text { Answers on serial health risk } \\
\text { assessments over time, } \\
\text { satisfaction survey of } \\
\text { information value and access. }\end{array}$ \\
\hline & $\begin{array}{l}\text { Increased consumer educa- } \\
\text { tion }\end{array}$ & $\begin{array}{l}\text { Trusted, authoritative, filtered } \\
\text { expert online content. }\end{array}$ & $\begin{array}{l}\text { Site visits, satisfaction survey of } \\
\text { information value and access. }\end{array}$ \\
\hline & Improved medication safety. & $\begin{array}{l}\text { Multiple expert drug interactions } \\
\text { and patient education leaflets. }\end{array}$ & $\begin{array}{l}\text { Site visits, detected potential } \\
\text { major drug interactions. }\end{array}$ \\
\hline & $\begin{array}{l}\text { Private communications } \\
\text { (with provider and } \\
\text { pharmacy). }\end{array}$ & $\begin{array}{l}\text { Secure, private communications to } \\
\text { ask about last visit or medica- } \\
\text { tions, request an appointment, } \\
\text { or receive online lab results. }\end{array}$ & $\begin{array}{l}\text { Satisfaction survey of } \\
\text { information value and access, } \\
\text { telephone time versus private } \\
\text { communications time. }\end{array}$ \\
\hline $\begin{array}{l}\text { Patients with } \\
\text { congestive } \\
\text { heart failure } \\
\text { (CHF) or } \\
\text { diabetes } \\
\text { mellitus } \\
\text { (DM) }\end{array}$ & $\begin{array}{l}\text { Online disease state } \\
\text { management (DSM). }\end{array}$ & $\begin{array}{l}\text { Condition-specific online DSM } \\
\text { for persons with CHF or DM and } \\
\text { patient- and condition-specific } \\
\text { information pushes via private } \\
\text { communications. }\end{array}$ & $\begin{array}{l}\text { Measures of consumer } \\
\text { understanding and } \\
\text { knowledge. DM: } \\
\text { glycohemoglobin, emergency } \\
\text { department visits, hypo- } \\
\text { glycemic events, ketotic } \\
\text { events, satisfaction of } \\
\text { information value and access. } \\
C H F \text { : body weights, shortness } \\
\text { of breath, dyspnea on exertion, } \\
\text { nocturnal dyspnea, adherence } \\
\text { to appropriate diet, recogni- } \\
\text { tion of edema. }\end{array}$ \\
\hline \multirow[t]{3}{*}{ Providers } & Increased market share. & Membership. & $\begin{array}{l}\text { Loyalty and allegiance to } \\
\text { system as determined by } \\
\text { online surveys. }\end{array}$ \\
\hline & $\begin{array}{l}\text { Prevention-based revenue } \\
\text { generation. }\end{array}$ & $\begin{array}{l}\text { Person-specific risk reduction mes- } \\
\text { sage pushes, customized links to } \\
\text { online information and challenges } \\
\text { to improve, invitation community- } \\
\text { based programs (e.g., smoking- } \\
\text { cessation classes), and online } \\
\text { DSM. }\end{array}$ & $\begin{array}{l}\text { Emergency department visits } \\
\text { for specific DRG or ICD9 } \\
\text { codes, admission rates, } \\
\text { unscheduled office visit rates. }\end{array}$ \\
\hline & $\begin{array}{l}\text { Enhanced patient consumers, } \\
\text { improved consumer and } \\
\text { access, satisfaction. }\end{array}$ & $\begin{array}{l}\text { Locally branded Winona Health } \\
\text { and privileges of membership, } \\
\text { person-specific risk reduction } \\
\text { message pushes, customized } \\
\text { links to online information and } \\
\text { challenges to improve, invitation } \\
\text { to community-based programs } \\
\text { (e.g., smoking-cessation classes), } \\
\text { and online DSM. }\end{array}$ & $\begin{array}{l}\text { Satisfaction survey of } \\
\text { patient information value } \\
\text { allegiance to provider } \\
\text { and local healthcare } \\
\text { system. }\end{array}$ \\
\hline Employers & $\begin{array}{l}\text { Improved productivity, } \\
\text { healthier-employees, } \\
\text { reduced risk for self- } \\
\text { insured employers. }\end{array}$ & $\begin{array}{l}\text { Membership pushes sponsored by } \\
\text { employers, person-specific risk } \\
\text { reduction message pushes, cus- } \\
\text { tomized links to online informa- } \\
\text { tion andchallenges to improve, } \\
\text { invitationcommunity-based } \\
\text { programs (e.g., smoking-cessation } \\
\text { classes), and online DSM. }\end{array}$ & $\begin{array}{l}\text { Days missed from work, } \\
\text { participation rates in } \\
\text { interventions such as } \\
\text { smoking-cessation programs. }\end{array}$ \\
\hline
\end{tabular}


four message types. Each message type has its own template format so that consumers and patients do not overwhelm busy clinicians with large quantities of free text messages. Instead, patients must choose from preselected message types and provide certain information before sending the message. The message types are: "Ask about my medications," "Ask about my last visit," "Request an appointment," and "Request a medication renewal or refill." Providers can send physician-interpreted laboratory results, answer questions, and forward prescription renewals to online pharmacies. Pharmacists can batch renewal requests to providers and notify patients that their filled prescription is ready.

The PHR is a portable Web-enabled tool for consumers to keep track of their personal health, medications, HRA reports, healthcare costs, and personal wellness plans. Folders within "Personal Health" include allergies, diagnoses, medical visits, immunizations, injuries, medical tests, surgeries, symptoms, measurements, and vision.

\section{OUTCOMES MEASUREMENT METHODS}

The null hypothesis states "there is no impact on the health of members associated with the use of WHOL (as measured by 'data elements' in Table 1)." Members are adults in the zip code capture area that register, complete the HRA, and become validated by a recognized authority in the community by photo identification. The impact of WHOL will be measured by comparing future data against baseline data among members or users of WHOL and among nonmembers or nonusers of WHOL. In addition, changes in health will be correlated with usage among members to minimize or eliminate self-selection bias. In addition, patients with CHF or DM will be randomized to "online DSM" or "no online DSM" for measurement of the effectiveness of engaging patients with online DSM.

There are two main areas of focus: improvements in community health and improvements in the outpatient management of two chronic disease states-CHF and DM (types I and II).

The following four key areas will be measured: access to healthcare information and healthcare, service and satisfaction, utilization and cost, and clinical quality measures. We will focus on data that are electronically available, directly affected by WHOL, occur frequently, can be compared to existing benchmarks, and that are unlikely to be affected by confounding factors. Table 1 shows the data elements that will be measured to show benefits by "user type."

\section{CONCLUSION}

Measurements of outcomes associated with the use of WHOL will help to show the value of connecting communities with interactive and personalized healthcare information. This is the first example of using online DSM tools to "get into the living rooms" of persons with specific chronic conditions. Many consumers are used to conducting business over the Web. WHOL represents a logical extension of this model into healthcare. Based on Internet usage data and expectations of consumer populations like baby boomers, there is incredible opportunity to impact the lives of millions of people with this new idea and technology.

Address reprint requests to: Douglas J. Pousma, M.D. Medical Director of Cerner-IQHealth 3200 South Cherry Creek Drive Suite 300 Denver, CO 80209

E-mail: dpousma@iqhealth.com 